\title{
FEMENISME WACANA SARA MILLS PADA NOVEL DEWI LESTARI AROMA KARSA
}

\author{
Yerry Mijianti ${ }^{1}$ \\ Pascasarjana UNS, Universitas Muhammadiyah Jember ${ }^{1}$ \\ yerry.mijianti@unmuhjember.ac.id \\ Desi Karolina Saragih ${ }^{2}$ \\ Pascasarjana UNS, Universitas Pamulang Tangerang Selatan ${ }^{2}$ \\ dosen01414@unpam.ac.id \\ Sumarlam $^{3}$ \\ Universitas Sebelas Maret ${ }^{3}$ \\ sumarlamwd@gmail.com
}

\begin{abstract}
ABSTRAK
Tujuan penelitian ini untuk mengungkapkan ketidak adilan gender femenisme dalam Novel Dewi Letari Aroma Karsa dimana Laki-laki dianggap sebagai pihak yang mampu berpikir logis, abstrak, dan analitis. Sedangkan perempuan adalah makhluk yang emosional, penyayang dan pemelihara. Konsep semacam ini berdampak pada kehidupan pribadi dan publik perempuan. Metode yang digunakan untuk menganalisa wacana kritis (Critical Discourse Analysis) pendekatan model Sara Mills menjelaskan posisi subjek-objek, serta bagaimana pembaca ditempatkan dalam teks dengan pengamatan Novel Aroma Karsa dengan pengumpulan data isi teks dialog dalam novel. Hasil penelitian Subjek penceritaan dalam novel Aroma Karsa adalah pengarang (perempuan). Objek penceritaan dalam novel Aroma Karsa adalah Raras Prayagung, Jati Wesi, dan Tanaya Suma. (2) Novel Aroma Karsa menempatkan khalayak sebagai perempuan karena pengarang adalah seorang perempuan. Teks ini ditujukan pada pembaca perempuan. Pembaca menempatkan dirinya pada posisi perempuan.
\end{abstract}

Kata Kunci: Femenisme,Sara Mills, Novel,Critikal Discourse Analysis

\section{A. PENDAhULUAN}

Male dan female merupakan pembedaan jenis kelamin berdasarkan perbedaan biologis dan hakikat alamiah manusia. Kedua jenis kelamin manusia tersebut memiliki perbedaan kejiwaan dan kebudayaan sehingga muncullah istilah maskulin dan feminin. Laki-laki dianggap sebagai pihak yang mampu berpikir logis, abstrak, dan analitis. Sedangkan perempuan adalah makhluk yang emosional, penyayang dan pemelihara. Konsep semacam ini berdampak pada kehidupan pribadi dan publik perempuan. Konsep pembeda laki-laki dan perempuan tesebut diwujudkan dalam aturan perilaku bahwa sebagai istri, ibu, dan anak seorang perempuan akan dibatasi partisipasinya di ruang publik dan harus dikontrol secara ketat oleh perwakilan otoritas yang maskulin seperti suami, ayah, kakak, agamawan, dan 
Lingua Rima: Jurnal Pendidikan Bahasa dan Sastra Indonesia

Vol. 11 No. 1 Januari 2022

http://jurnal.umt.ac.id/index.php//grm

hukum (Gaviota, 2021: 58). Konsep feminin dan maskulin menimbulkan kondisi perempuan yang dimarginalisasi, disubordinasi, dan direndahkan. Hal ini membuat kaum perempuan berjuang mendapatkan hak kehidupan dan hak demokrasi di bidang politik, ekonomi, dan sosial (Darma, 2013: 139). Perjuangan menyamakan hak oleh para perempuan ini kemudian memunculkan istilah feminis dan feminisme.

Feminis berasal dari kata femme yang berarti perempuan. Feminis adalah perjuangan kaum perempuan untuk menolak segala sesuatu dari diri perempuan yang dimarginalisasikan (pembatasan), disubordinasikan (kedudukan bawah), dan direndahkan oleh budaya dominan dalam bidang politik, ekonomi, dan sosial (Darma, 2013: 140). Gerakan dan perjuangan para perempuan ini kemudian dikembangakn menjadi sebuah faham (idelogis) yang disebut feminisme. Feminisme adalah faham perempuan yang menyamakan hak, status, kesempatan, peranan, serta kepentingan perempuan dalam masyarakat. Dengan demikian, feminis adalah sebutan untuk orang yang menganut paham feminisme.

Sara Mills merupakan penganut analisis wacana pendekatan perancis yang bersumber dari Michel Foucault. Sebagai seorang feminis, Sara Mills menggambarkan relasi kekuasaan dan ideologi tentang perempuan yang ditampilkan dalam teks (novel, gambar, foto, berita) (Darma, 2014: 122). Sudut pandang Sara Mills ini memosisikan dirinya sebagai pemerhati wacana berperspektif feminis. Wacana berperspektif feminis menitikberatkan pada : (1) bagaimana posisi aktor ditampilkan dalam teks, (2) bagaimana pembaca dan penulis ditampilkan, dan (3) bagaimana pembaca mengidentifikasi dan menempatkan dirinya dalam penceritaan teks (Darma, 2014: 123). Masalah-masalah feminis menjadi perhatian Sara Mills dalam sebuah teks yaitu posisi penulis dan khalayak serta bagaimana seorang tokoh ditempatkan dalam subjek tertentu.

Kajian feminis telah dilakukan oleh peneliti terdahulu. Fitrianingtyas, Cahyono, dan Soleh (2021) menemukan adanya diskriminasi dan superioritas perempuan dalam bidang sosial dan kekuasaan atau penguasaan perempuan dalam hal ekonomi pada Naskah Drama Mega-Mega karya Arifin C. Noer. Selain mereka peneliti berikut juga menganalisi feminisme dalam karya sastra. Rahayu, Setiadi, dan Firdaus (2021) menemukan enam tokoh perempuan mengalami ekploitasi dan ketidakadilan dalam Novel Biru karya Fira Basuki. Penelitian tentang feminisme berikutnya menganalisis perempuan dari media massa. Wardani, Purnomo, dan Lahade (2013) merepresentasikan perempuan dalam citra yang baik yaitu sebagai objek (yang diceritakan) sekaligus sebagai subjek (pencerita) tentang kesuksesannya dalam bidang publik (prodiktif atau sosial) dan domestik. Penyiar radio sebagai subjek mengangkat kiprah perempuan dalam berbagai bidang. Pendengar memosisikan dirinya untuk 
Lingua Rima: Jurnal Pendidikan Bahasa dan Sastra Indonesia

Vol. 11 No. 1 Januari 2022

http://jurnal.umt.ac.id/index.php//grm

berpihak pada sosok wanita inspiratif yang disiarkan oleh penyiar radio dalam acara Tupperware She Can! On Radio yang disiarkan oleh Radio Female Semarang.

Berbagai kajian femisime di atas menginspirasi penulis untuk melakukan kajian feminis tentang posisi subjek dan objek serta posisi pembaca dalam sebuah novel berjudul Aroma Karsa karya Dewi Lestari. Tak hanya menulis novel, Dewi Lestari juga menulis buku tentang proses kreatifnya dalam menulis Aroma Karsa. Dengan dua karya tersebut maka pembaca mendapatkan sesuatu yang utuh tentang Aroma Karsa. Dewi Lestari sebagai penulis novel telah menelurkan gagasan dalam sebuah novel dan mengiringinya dengan gagasan tentang proses kreatif penulisan novel. Dewi Lestari memberikan sumbangan kepada pembaca tentang posisi penulis dan khalayak serta bagaimana seorang tokoh ditempatkan. Dalam novelnya yang berjudul Aroma Karsa, Dewi Lestari menggambarkan tokoh perempuan bernama Raras Prayagung yang memiliki obsesi menemukan Puspa Karsa. Bunga dengan keharuman yang istimewa tersebut mampu memikat dan memengaruhi siapa pun yang mencium aromanya.

Puspa Karsa yang dikenal oleh Raras Prayagung sebagai dongeng ternyata tanaman yang benar-benar ada dan tersembunyi di tempat rahasia. Dengan segala upaya, waktu yang lama, dan mengorbankan banyak hal, Raras prayagung menemukan Puspa Karsa. Novel ini diterbitkan pertama kali pada tahun 2018 oleh Penerbit Bentang di Yogyakarta setebal 710 halaman. Selain menulis novel, Dewi Lestari juga menulis buku tentang proses kreatifnya menulis novel Aroma Karsa dengan judul Di Balik Tirai Aroma Karsa. Buku setebal 318 halaman ini diterbitkan oleh Penerbit Bentang di Yogyakarta tahun 2019. Kehadiran dua buku tersebut melengkapi pemaknaan pembaca secara utuh tentang sebuah teks yaitu posisi aktor, pembaca, dan penulis dalam penceritaan teks. Tujuan penelitian ini yaitu 1) mengetahui posisi subjek dan objek dalam Novel Aroma Karsa karya Dewi Lestari, 2) mengetahui posisi pembaca dalam novel Aroma Karsa karya Dewi Lestari.

Feminisme adalah gerakan untuk mengakhiri seksisme (penggunaan kata atau frasa yang meremehkan atau menghina), eksploitasi seks (pemanfaataan seks untuk keuntungan sendiri), dan penindasan terhadap perempuan (Gaviota, 2021: 2). Istilah feminisme digunakan untuk mewakili gerakan politik, budaya, dan ekonomi untuk menegakkan persamaan hak dan perlindungan hukum bagi perempuan. Gerakan untuk menciptakan sebuah dunia yang damai penuh kasih tanpa rasialisme (perlakuan yang berat sebelah terhadap suku bangsa yang berbeda-beda), elitisme kelas (pengelompokan dalam masyarakat, misalnya bangsawan, cendekiawan, atau priyayi), dan imperialisme (penjajahan negara lain 
Lingua Rima: Jurnal Pendidikan Bahasa dan Sastra Indonesia

Vol. 11 No. 1 Januari 2022

http://jurnal.umt.ac.id/index.php//grm

untuk mendapatkan kekuasaan dan keuntungan yang lebih besar) dengan filosofi bahwa semua orang diciptakan sederajat.

Feminisme memberikan gagasan kepada perempuan untuk tidakk lagi melihat diri dan tubuh mereka sebagai milik laki-laki. Perempuan dapat menuntut kendali seksualitas, pengendalian kelahiran, hak reproduksi yang efektif, serta tuntutan hukuman untuk pemerkosaan dan pelecehan seksual (Gaviota, 2021: 17). Perempuan dapat mengekspresikan hasrat seksual dan mengenal kenikmatan seksual. Hal ini membuat perempuan memerlukan alat kontrasepsi yang dapat diandalkan dan aman sehingga ia memiliki kontrol penuh atas hasil dari aktivitas seksual. Dominasi laki-laki dan kekerasan masih terjadi di kalangan lakilaki pengangguran dan laki-laki kelas pekerja. Hal ini terjadi karena laki-laki membutuhkan otoritas dan rasa hormat. Ketika banyak laki-laki menerima upah rendah dan permepuan banyak yang memasuki dunia kerja, maka beberapa laki-laki menggunakan kekerasan untuk mempertahankan kekuasaan dan dominasi dalam hierarki peran seksis. Feminisme memberikan gagasan bahwa perempuan dan laki-laki harus menentang penggunaan kekerasan (kekerasan laki-laki terhadap perempuan, kekerasan dewasa terhadap anak, kekerasan remaja, dan kekerasan rasial) sebagai alat kontrol sosial.

Feminisme memfokuskan pola pengasuhan anak tanpa seksisme. Anak-anak perlu dibesarkan di dalam lingkungan yang penuh kasih sehingga mereka tumbuh menjadi manusia yang sehat, bahagia, dan memiliki harga diri yang baik. Pengasuhan dari orang tua lengkap atau orang tua tunggal yang dilakukan dengan pemikiran dan perilaku antiseksis akan memberikan kesempatan pada anak laki-laki dan anak perempuan untuk melihat femisime di dalam tindakan (Gaviota, 2021: 44-45). Dominasi dapat berakhir jika cinta makin banyak diberikan. Orang tua harus mengakhiri dominasi patriarki terhadap anak-anak sehingga keluarga menjadi tempat yang aman bagi anak.

Banyak perempuan dalam gerakan feminis menginginkan pembebasan. Kemandirian ekonomi diperlukan jika perempuan ingin dibebaskan dari dominasi laki-laki. Kapitalisme konsumen mengarahkan banyak perempuan untuk memasuki dunia kerja. Dengan memasuki dunia kerja, harga diri mereka meningkat dan dapat melakukan partisipasi positif dalam masyarakat. Pekerjaan yang membebaskan perempuan bukan pekerjaan yang setara dengan laki-laki, bukan hanya bergaji tinggi, tetapi jenis pekerjaan memiliki jadwal waktu yang nyaman dan gaji yang jelas dan layak. Selain jenis pekerjaan, kemandirian ekonomi perempuan dapat diwujudkan dengan gaya hidup alternatif yang bertentaangan dengan citra kehidupan baik yang disajikan oleh media massa patriarkal kapitalis supremasi kulit putih (Gaviota, 2021: 82). Artinya, perempuan mampu menentukan sendiri standar kecantikan, 
Lingua Rima: Jurnal Pendidikan Bahasa dan Sastra Indonesia

Vol. 11 No. 1 Januari 2022

http://jurnal.umt.ac.id/index.php//grm

kesehatan, dan kekayaan dirinya tanpa pengaruh iklan dan omongan orang lain di masyarakat. Feminisme memberikan sumbangsih gagasan perkerjaan yang baik untuk perempuan, yaitu pekerjaan yang mengarah pada kemandirian ekonomi, meningkatkan kualitas hidup, dan memfasilitasi kesejahteraan.

Hak reproduksi bagi perempuan segala usia menjadi fokus berikutnya dari feminisme. Hak reproduksi dibutuhkan perempuan untuk melindungi dan mempertahankan kebebasan perempuan (Gaviota, 2021:89-90). Kebebasan dari kehamilan yang tidak direncanakan, kehamilan yang tidak diinginkan, dan aborsi. Untuk itu, perempuan perlu membekali diri dengan pendidikan seks dasar, perawatan pranatal, perawatan kesehatan preventif, dan pengetahuan tentang alat kontrasepsi yang handal dan aman. Dengan berbekal pengetahuan tersebut perempuan diharapkan memahami cara kerja tubuh mereka sehingga mereka tidak perlu mengalami sterilisasi paksa, operasi caesar, histerektomi (operasi pengangkatan rahim) yang tidak perlu, serta komplikasi medis akibat operasi medis.

Impian feminis adalah mengganti budaya dominasi dengan dunia ekonomi partisipasif yang didasarkan pada komunalisme (mementingkan kebersamaan di dalam kelompok) dan sosial demokrasi (persamaan hak, kewajiban, dan perlakuan yang sama dalam masyarakat). Sebuah dunia tanpa diskriminasi ras atau gender. Sebuah dunia yang mengakui mutualisme (hubungan timbal balik yang saling menguntungkan) dan saling ketergantungan. Sebuah dunia dengan visi ekologi global tentang cara bertahan hidup dan usaha untuk memperoleh perdamaian dan kesejahteraan (Gaviota, 2021: 94-95). Untuk itu, feminis mengenalkan politik feminis. Politik feminis yaitu cinta memiliki kekuatan untuk melawan dominasi. Feminisme memungkinkan perempuan dan laki-laki mengenal cinta. Cinta yang berakar pada pengakuan, penerimaan, perhatian, tanggung jawab, komitmen, keadilan, dan pengetahuan. Laki-laki dan perempuan dapat bermitra. Kemitraan yang saling menguntungkan adalah fondasi cinta. Perempuan dan laki-laki perlu menciptakan institusi berdasarkan prinsipprinsip politik feminis. Dengan demikian gerakan feminis dapat dilakukan semua orang. Upaya kolektif ini dapat menyebarkan pesan-pesan feminisme yaitu gerakan mengakhiri seksisme, dominasi, penindasan, diskrimansi gender, dan menciptakan kesetaraan.

Sara Mills mengenalkan konsep wacana berperspektif feminis yaitu mengupas bagaimana perempuan ditampilkan dalam teks (novel, gambar, foto atau berita). Terdapat dua hal yang diperhatikan Sara Mills yaitu tingkat posisi subjek-objek dan tingkat posisi penulispembaca (Darma, 2014:154-155). Pertama, bagaimana peristiwa dilihat, dari kacamata apa peristiwa itu dilihat, siapa yang diposisikan sebagai pencerita (subjek), sispa yang diposisikan sebagai objek yang diceritakan, apakah masing-masing memiliki kesempatan menampilkan 
Lingua Rima: Jurnal Pendidikan Bahasa dan Sastra Indonesia

Vol. 11 No. 1 Januari 2022

http://jurnal.umt.ac.id/index.php/lgrm

diri, gagasan, atau kehadirannya atau ditampilkan oleh orang lain atau kelompok lain. Kedua, bagaimana pembaca diposisikan dalam teks, bagaimana pembaca memposisikan dirinya, kepada kelompok mana pembaca mengidentifikasi diri.

Posisi subjek dan objek oleh Sara Mills dilihat dari berbagai faktor sosial, posisi gagasan, atau peristiwa ditempatkan dalam wacana. Posisi tersebut menentukan : (1) siapa menjadi subjek penceritaan, (2) siapa menjadi objek penceritaan (Darma, 2021: 198-199). Kedua posisi ini akan menentukan struktur teks dan makna teks atau makna wacana secara keseluruhan. Subjek penceritaan mendefenisikan dan melakukan penceritaan. Objek penceritaan sebagai pihak yang didefinisikan dan digambarkan kehadirannya oleh orang lain.

Posisi pembaca sangat penting dalam pandangan Sara Mills. Teks adalah hasil negosiasi antara penulis dan pembaca. Pembaca tidak hanya menerima teks tetapi juga melakukan transaksi. Dengan demikian, teks berhubungan dengan faktor produksi dan resepsi. Teks secara tidak langsung berkomunikasi dengan pembaca. Wujud komunikasi tersebut tampak dari penggunaan kata ganti dalam sebuah wacana. Ketika pengarang menulis, ia juga memperhitungkan posisi pembaca. Kehadiran pembaca dalam teks dapat menarik dukungan dan simpati hingga mampu meyakinkan pembaca. Sara Mills memusatkan perhatian pada gender dan posisi pembaca (Darma, 2013: 200). Artinya, persepsi antara lakilaki dan perempuan terhadap teks akan memiliki perbedaan, begitu pula cara memosisikan teks. Dengan demikian, terdapat dua konsep yaitu : (1) teks ditujukan untuk pembaca lakilaki atau pembaca perempuan, (2) teks ditafsirkan oleh pembaca. Sebuah teks yang ditujukan pada pembaca laki-laki akan memiliki dua kemungkinan yaitu pembaca laki-laki menempatkan dirinya pada posisi laki-laki atau pembaca laki-laki menempatkan dirinya pada posisi perempuan. Sebuah teks yang ditujukan pada pembaca perempuan akan memiliki dua kemungkinan pula, yaitu pembaca perempuan menempatkan dirinya pada posisi perempuan atau pembaca perempuan menempatkan dirinya pada posisi laki-laki.

Aroma Karsa merupakan buku kedua belas karya Dewi Lestari yang dikenal dengan nama pena Dee Lestari. Aroma Karsa tampil lebih dulu dalam versi digital yang diterbitkan penerbit digital Bookslife berupa cerita bersambung. Pengemasan cerita bersambung ini ditujukan untuk pembaca milenial agar kembali ke masa membaca cerita bersambung, tetapi dengan versi kekinian. Kemudian, Aroma Karsa tampil dalam versi cetak pada tahun 2018. Kemunculan Aroma Karsa dalam dua versi yang berbeda waktu ini membuat pembaca sangat menerima kedatangan novel yang bercerita tentang indera penciuman dan bunga anggrek ini. Hal ini membuahkan penghargaan Book of The Year 2018 dari IKAPI (Ikatan Penerbit Indonesia) bagi versi cetak novel berjudul Aroma Karsa. 
Lingua Rima: Jurnal Pendidikan Bahasa dan Sastra Indonesia

Vol. 11 No. 1 Januari 2022

http://jurnal.umt.ac.id/index.php//grm

Aroma Karsa menceritakan tentang tokoh perempuan bernama Raras Prayagung yang mengetahui bahwa Puspa Karsa yang dikenalnya sebagai dongeng ternyata ditulis dalam sebuah lontar kuno dan ternyata tanaman sungguhan yang tersembunyi di tempat rahasia. Raras memburu Puspa Karsa, bunga yang mampu mengendalikan kehendak dan hanya bisa ditemukan melalui aroma. Raras lalu bertemu dengan Jati wesi, pria muda yang memiliki penciuman luar biasa, di TPA (Tempat Pembuangan Akhir) Bantar Gebang. Kemampuan Jati memikat Raras untuk memperkerjakan Jati di perusahaannya sekaligus mewujudkan obsesi Raras menemukan Puspa Karsa. Jati bertemu dengan anak tunggal Raras yang bernama Tanaya Suma. Tanaya memiliki kemampuan serupa dengan Jati. Jati kemudian menemukan tentang jati dirinya yang sesungguhnya dan masa lalu yang tak pernah ia tahu.

Selain Aroma Karsa, Dee Lestasi juga menulis Di Balik Tirai Aroma Karsa. Buku yang berisi proses kreatif penulis dalam melahirkan sebuah karya ini ditulis Dee pada tahun yang sama dengan novel Aroma Karsa. Dalam buku ini Dee menguak misteri di balik lahirnya novel Aroma Karsa. Di sini Dee mengulas secara detil proses kreatif penulisan Aroma Karsa mulai dari riset hingga pemasaran. Melalui buku ini, pembaca dapat mengetahui jatuh bangun, tantangan, sekaligus alasan dari berbagai keputusan kreatif seorang penulis.

\section{B. METODELOGI PENELITIAN}

Jenis penelitian ini adalah penelitian analisis isi kualitatif. Penelitian analisis isi kualitatif adalah pemeriksaan yang telioti berbentuk pembahasan mendalam terhadap isi suatu informasi dalm benntuk tertulis dan tercetak dengan menggunakan pendekatan kaulitatif (Tim Penyusun, 2019: 63-65). Setting penelitian dilakukan selama dua bulan, yaitu Bulan September hingga November tahun 2021. Waktu dua bulan tersebut digunakan untuk dua pekan persipan penelitian, tiga pekan pengumpulan data, dan tiga pekan untuk analisis data. Komponen isi analisis meliputi rumusan masalah, sampel sumber data, pengakategorian fokus, sajian data, kriteria pengumpulan data, dan penafsiran data. Pengkategorian fokus yaitu pada posisi subjek dan objek serta posisi pembaca terhadap novel Aroma Karsa. Sajian data dilakukan secara deskriptif berupa kalimat yang dicetak miring. Kriteria pengumpulan data yaitu kalimat-kalimat yang mengandung posisi subjek dan objek serta posisi pembaca. Penafsiran data dilakukan dengan menelaah sesuai dengan teori analisis wacana berperspektif feminisme. Sumber data berupa dokumentasi yaitu novel Aroma Karsa yang telah mendapat penghargaan dari IKAPI tahun 2018. Tenik pengumpulan data menggunakan teknik dokumentasi dan teknik catat. Instrumen pengumpulan data berupa catatan dan alat tulis. Keabsahan data berupa construct validity yaitu derajat kesesuaian teori analsisi wacana 
Lingua Rima: Jurnal Pendidikan Bahasa dan Sastra Indonesia

Vol. 11 No. 1 Januari 2022

http://jurnal.umt.ac.id/index.php//grm

berperspektif feminisme dengan konsep posisi subjek dan objek serta posisi pembaca dalam Aroma Karsa. Analisis data menggunakan analisis penelitian kualitatif.

\section{HASIL PENELITIAN DAN PEMBAHASAN}

Pada bagian hasil penelitian ini, penulis memaparkan hasil analisis secara deskripstif. Berdasarkahn hasil penelitian menggunakan analisis wacana berperspektif feminis diperoleh posisi subjek dan objek serta posisi pembaca.

1. Posisi Subjek dan Objek

Novel Aroma Karsa bercerita tentang kegigihan tokoh utama perempuan, Raras Prayagung, mewujudkan cita-citanya menemukan dan mendapatkan Puspa Karsa. Bahasa yang digunakan pengarang, Dewi Lestari, dalam menyajikan cerita adalah bahasa komunikasi sehari-hari dengan diselingi kata-kata dan kalimat yang indah. Tokoh cerita adalah Raras Prayagung (pemilik perusahaan parfum yang terobsesi menemukan dan mendapatkan bunga istimewa, Puspa Karsa), Jati Wesi (pemuda yang memiliki penciuman luar biasa), dan Tanaya Suma (anak tunggal Rarastokoh utama perempuan Prayagung yang memiliki penciuman luar biasa pula). Dalam novel ini pengarang berada di luar cerita saat menampilkan tokoh cerita dengan menggunakan kata ganti ketiga (ia, -nya, mereka, nama tokoh cerita). Pengarang menceritakan segala sesuatu yang berhubungan dengan tokoh yang dapat diindera dan yang dirasakan tokoh cerita.

Subjek penceritaan adalah orang yang mendefenisikan dan melakukan penceritaan. Subjek penceritaan dalam novel Aroma Karsa adalah pengarang (perempuan). Objek penceritaan adalah orang yang didefiniskan dan digambarkan kehadirannya oleh orang lain. Objek penceritaan dalam novel Aroma Karsa adalah Raras Prayagung, Jati Wesi, dan Tanaya Suma.

Citra perempuan yang digambarkan salam tokoh Raras Prayagung adalah perempuan yang gigih, tahu apa yang diinginkan, mahir bernegosiasi, mengenal kelebihan dan kemampuan diri, tidak menikah namun memiliki anak angkat, pekerja keras sehingga memimpin perusahaan warisan keluarga.

Perempuan yang gigih dari tokoh Raras Prayagung tampak pada kutipan berikut.

"Di mana, Eyang? Bisa dicari di mana?" Jika sepersepuluhsaja yang diceritakan neneknya tentang Puspa Karsa selama ini benar, Raras siap melanglang ke mana pun. Semangat dan keingintahuannya berbuihbuih.(Lestari, 2020:4). 
Lingua Rima: Jurnal Pendidikan Bahasa dan Sastra Indonesia

Vol. 11 No. 1 Januari 2022

http://jurnal.umt.ac.id/index.php//grm

Kutipan tersebut menggambarkan semangat Raras untuk mewujudkan keinginannya yaitu menemukan dan mendapatkan Puspa karsa yang diceritakan neneknya. Selain kutipan tersebut, kegigihan Raras Prayagung tampak pada kutipan berikut.

Raras selalu mengatakan ia butuh lebih banyak waktu, sedang menunggu seuatu. Apa pun itu, agaknya Raras telah mendapatkannya. Percayalah, Mas. Saya sama kepinginnya dengan Mas Lambang mewujudkan ekspedisi ini. "Jujur, masih seperti mimpi. Saya pikir setelah ekspedisi yang pertama, Mbak kapok mencoba lagi," kata Lambang. "Saya ini Prayagung, Mas. Nggak kenal kapok." Raras tertawa ringan. "Selama ini saya cuma menunggu terkumpulnya orang-orang yang pas. Sekarang orang-orangnya sudah ketemu." (Lestari, 2020: 297-298).

Kutipan di atas menggambarkan kegigihan Raras mewujudkan cita-citanya menemukan Puspa Karsa. Kegigihan tersebut tampak dari dialognya dengan Lambang, seorang Profesor di bidang arkelogi. Mereka pernah melakukan pencarian Puspa karsa pada ekspedisi pertama namun gagal. Lalu mereka melakukan pencarian kedua melalui ekspedisi kedua.

Citra perempuan yang tahu apa yang diinginkan tampak pada kutipan berikut.

Raras sesungguhnya merasa diuntungkan dengan putisnya Jindra dari ikatan militer. Ia jadi punya orang pegangan yang memiliki fleksibilitas waktu dan keleluasaan bekerja di luar sistem. Alasan Jindra dikeluarkan justru menjadi sebab kuat bagi Raras memercayainya. Meyakini keberpihakannya. "Kapan terakhir kali kamu masuk hutan?" Raras tidak buang-buang waktu. "Sudah terlalu lama, Bu," jawab Jindra. "Ada apa ini?" "Ekspedisi." "Kedengaarannya serius." "Kalau proyek main-main, masa saya bawa ke Jindra Mahameru?” (Lestari, 2020:216).

Kutipan di atas menggambarkan sosok Raras yang tahu apa yang diinginkannya. Membaca kondisi, memilih orang, dan yakin dengan pilihannya telah dilakukan Raras untuk mewujudkan keinginannya melakukan ekspedisi kedua pencarian Puspa Karsa. Citra perempuan berikutnya dari sosok Raras adalah mahir bernegosiasi. Kemahirannya berunding dan membuat pihak lain menyetujui tawarannya tampak pada kutipan berikut.

"Kalau saya setuju untuk ikut, apakah kompensasinya harus memilih salah satu? Atau bisa keduanya?" "Dibayar pakai duit atau pakai anggrek, begitu?" Iwan sadar posisi Raras yang di atas angin. Ekspedisi tanaman fantasi itu bukan bisa menjadi jalan keluar dari kondisi keuangannya yang kritis. Bukan jalan ideal. Tapi, saat ini Iwan tidak punya keleluasaan untuk pilih-pilih. "Jika Iwan Satyana ada di tim ini, memberikan verifikasi atas tanaman yang akan mengubah sejarah, bagi saya itu sangat berharga. Tentu saja bisa saya atur agar keduanya jalan, Mas. Saya tidak mungkin hitung- 
Lingua Rima: Jurnal Pendidikan Bahasa dan Sastra Indonesia

Vol. 11 No. 1 Januari 2022

http://jurnal.umt.ac.id/index.php//grm

hitungan. Tidak semuanya diukur dengan uang, toh?" Dengan bantuan tongkat, Raras berdiri, lalu mengulurkan tangannya. Telapak tangan Iwan masih bersisa percikan pupuk cair dan media tanam, tapi jabat tangan Raras terlalu menggiurkan untuk ditepiskan. Iwan pun menyambutnya mantap. "Selamat bergabung," ucap Raras (Lestari, 2020:314).

Kutipan di atas menunjukkan kemahiran Raras dalam mencapai kesepakatan bersama dengan Iwan. Raras mampu menawar apa yang ditawarkan Iwan sebelumnya. Akibatnya, Iwan tergiur dan menyepakati tawaran Raras untuk bergabung dalam tim ekspedisi pencarian Puspa Karsa yang dibentuk Raras.

Citra perempuan berikutnya dari sosok Raras adalah mengenal kelebihan dan kemampuan diri. Kemampuan Raras menilai dirinya tampak p[ada kutipan berikut.

Raras Prayagung disebut-sebut sebagi Srikandi Modern, Kartini Masa Kini, dan julukan-julukan superior lainnya. Tak Cuma sekali ia dibidik pemerintah untuk menjabat menteri kabinet, tetapi Raras masih menolak dengan pertimbangan ingin memajukan Kemara hingga ke titik ia siap menyerahkan tongkat estafet berikut. Beban yang kini dipikul oleh Tanaya Suma, putri tunggalnya (Lestari, 2020:195).

Kutipan di atas menggambarkan bahwa Raras memiliki kemampuan yang istimewa dan diakui oleh pemerintah. Tetapi ia memutuskan bahwa kelebihan dan kemampuanya hanya digunakan untuk memajukan perusahaannya bukan yang lain.

Citra sebagai perempuan yang tidak menikah namun memiliki anak angkat adalah tampilan Raras selanjutnya. Kutipan berikut menggambarkan citra tersebut.

Suma. Cepat, Jati memindai ruangan. Di dinding, dekat televisi yang besarnya hampir setengah tembok, tergantunglah beberapa foto. Raras, dalam setelan kebaya berwarna merah, duduk di kursi bersandingan dengan seorang perempuan muda yang berdiri di belakangnya mengenakan kebaya serupa. Di bingkai lain, tampak perempuan muda itu berfoto sendirian mengenakan baju toga. Jati juga menangkap lukisan berpigura emas, ada perempuan itu dalam baju putih berenda, dilukis ketika masih kecil. Hanya ada gambar dia dan Raras di mana-mana, Jati tidak menemukan sosok laki-laki (Lestari, 2020: 122).

Kutipan di atas menunjukkan bahwa Raras hanya hidup berdua dengan Tanaya Suma di rumah itu. Jati, sebagai tamu di rumah itu, tidak menemukan foto laki-laki di di antara foto-foto Raras dan Suma di dinding runagan itu. Pada bagian ini pembaca dibuat penasaran sama pensarannya dengan tokoh Jati saat melihat fotofoto tersebut. Namun, pembaca akan menemukan jawabannya pada bab jauh 
Lingua Rima: Jurnal Pendidikan Bahasa dan Sastra Indonesia

Vol. 11 No. 1 Januari 2022

http://jurnal.umt.ac.id/index.php/lgrm

setelahnya. Jawaban atas rasa penasaran Jati serta pembaca tampak pada kutipan berikut.

"Bagaimana bayinya?" tanya Khalil. "Aku beri nama Suma. Artinya 'bunga'," ucap Raras berseri-seri. "Tanaya Suma. 'Anak bunga'." "Bagus." Khalil menyahut dengan nada mengambang. Ia terheran-heran mendapati kenyataan itu. Raras seperti ibu baru yang kehadiran bayinya mampu memupuskan segala susah dan musibah. Ekspedisi yang memakan korban tiga orang, nasib laki-laki gunung yang kini masuk penjara, terbunuhnya seorang perempuan, diculiknya seorang bayi, seolah tidak meninggalkan bekas sama sekali (Lestari, 2020: 588).

Kutipan di atas menunjukkan Raras mengangkat bayi perempuan menjadi anaknya dan diberi nama Tanaya Suma. Bayi perempuan itu adalah anak dari lakilaki gunung. Saat ekspedisi pertama, Raras berhasil mengobrak abrik tempat tersembunyi yang diduga lokasi Puspa Karsa dan berjumpa dengan sebuah keluarga. Namun, ekspedisi mengalami kegagalan. Tiga orang dari tim Raras meninggal. Sebuah keluarga yang ditemui Raras di gunung yang terdiri dari laki-laki gunung beserta istri, bayi perempuan, dan bayi laki-laki kabur dari gunung untuk menyelamatkan diri karena diburu oleh tim Raras.

Meskipun memiliki anak tetapi Raras tidak terikat pernikahan dengan seorang pria. Pada kutipan berikut ditunjukkan alasan Raras tidak menikah.

"Keputusanku sudah bulat. Aku memang ingin berhenti." Raras terdiam. Khalil tampak sungguh-sungguh. "Kita masih bisa kerja bareng, kan? Biarpun kamu sudah tidak di perusahaan?" tanyanya cemas. "Mungkin." Khalil mengangkat bahu. "Aku ingin menenangkan diri dulu." "Apa ini gara-gara ... kita?" "Bukan. Sama sekali”. Khalil menggeleng cepat. "Itu sudah berlalu. Aku bisa menerima kalau kamu memang tidak tertarik untuk ... memang tidak mungkin, Raras. Lupakan." "Kamu tahu perasaanku. Aku cuma belum siap -“"Aku tahu”. Kamu tidak akan pernah siap (Lestari, 2020:589).

Kutipan di atas menggambarkan bahwa Khalil dan Raras saling mencintai tetapi Raras memutuskan tidak melanjutkan percintaan mereka dalam sebuah rumah tangga. Dari kajian feminis, pilihan Raras termasuk isu hak reproduksi. Raras memilih hak reproduksi untuk mempertahankan kebebasan perempuan. Raras telah menentukan pilihan untuk tidak menikah karena ingin keluar dari sistem patriarki (perilaku mengutamakan laki-laki dalam masyarakat tertentu) yang tercermin dalam kehidupan rumah tangga. Aapa yang dipilih Raras ini adalah hasil pemikiarannya selama mengamati keluarganya, seperti pada kutipan berikutt. 
Lingua Rima: Jurnal Pendidikan Bahasa dan Sastra Indonesia

Vol. 11 No. 1 Januari 2022

http://jurnal.umt.ac.id/index.php/lgrm

Dari usia belia sekalipun, Raras dapat menilai ayahnya. Romo ibarat kutukan. Romo tidak kebagian secuil pun keuletan Janirah Prayagung. ... Romo kebanyakan perempuan simpanan. Romo terlalu lama menghabiskan waktu di lapangan golf dan klub pria. Di mata raras, Romo tidak pernah benar-benar mencintai istri dan anaknya. Mereka hanya barang pajangan agar satusnya sebagi pria komplet terjaga.

Dari sini tampak bahwa Raras mendapatkan konsep pernikahan yang buruk dari perilaku ayahnya. Hal inilah yang membuat Raras memutuskan tidak menikah. Citra yang terakhir yang digambarkan oleh tokoh Raras Prayagung adalah pekerja keras. Kutipan berikut menunjukkan kerja keras Raras membangun perusahaan yang diwarisi dari nenek dan ayahnya.

Kemara, pernah diambang pailit buah ketidakbecusan Romo, diambil alih oleh Raras ketika ia masih berumur dua puluh lima tahun, tak lama setelah lulus dari sarjana magister. ... Cukup lima tahun bagi Raras Prayagung untuk menyembuhkan Kemara. Ia disebut-sebut "anak ajaib". Pengusaha muda di bawah usia tiga puluh tahun yang berhasil menyeaematkan perusahaan tua dari tepi liang kubur dan kembali menyuntikkan energi kebaruan. Raras tak berhenti di sana. Lima tahun berikutnya, Kemara mengukuhkan diri sebagai perusahaan jamu dan kosmetik nomor satu dengan porsi pasar terbesar di Indoneosa. Ekspor mereka pun menggurita ke mana-mana (Lestari, 2021:16).

Kutipan di atas menunjukkan bahwa Raras adalah perempuan pekerja keras. Ia mengerahkan kemampuan dan energinya untuk mengibarkan bendera perusahaan keluarganya di kancah perbisnisan di Indonesia. Akibat mengerahkan seluruh daya dalam dirinya Raras terlena dan terlupa untuk urusan cinta dan larut dalam urusan perusahaan. Hal ini didukung dengan kutipan berikut.

Mereka lantas mengira itulah yang akan terjadi jika seorang perempuan mabuk karier dan menjadi terlampau hebat (Lestari, 2020: 16).

Kutipan di atas menggambarkan kondisi Raras Prayagung yang terus sibuk bekerja dan mengejar karier demi kemegahan perusahaan warisan keluarga dan melupakan cinta dan kehidupan rumah tangga.

2. Posisi Pembaca

Pengarang bercerita menggunakan sudut pandang orang ketiga. Teks ini menempatkan khalayak sebagai perempuan karena pengarang adalah seorang perempuan. Teks ini ditujukan pada pembaca perempuan. Pembaca menempatkan dirinya pada posisi perempuan baik sebagai Raras Prayagung saat pengarang menceritakan Raras Prayagung, dan sebagai Tanaya suma saat pengarang menceritakan Tanaya Suma. 
Lingua Rima: Jurnal Pendidikan Bahasa dan Sastra Indonesia

Vol. 11 No. 1 Januari 2022

\section{SIMPULAN DAN SARAN}

http://jurnal.umt.ac.id/index.php//grm

Berdasarkan pembahasan, maka simpulan dari penelitian ini yaitu : (1) Subjek penceritaan dalam novel Aroma Karsa adalah pengarang (perempuan). Objek penceritaan dalam novel Aroma Karsa adalah Raras Prayagung, Jati Wesi, dan Tanaya Suma. (2) Novel Aroma Karsa menempatkan khalayak sebagai perempuan karena pengarang adalah seorang perempuan. Teks ini ditujukan pada pembaca perempuan. Pembaca menempatkan dirinya pada posisi perempuan. Saran yang dapat penulis berikan adalah peneliti lain dapat menganalisi novel ini dari sudut pandamng ekologi sastra karena banyak dimunculkan hubungan timbal balik antara makhluk hidup dengan kondisi alam sekitarnya (lingkungannya), misalnya, indera penciuman dengan lingkungannya atau beragam bunga anggrek yang menjadi kekhasan Indonesia.

\section{E. DAFTAR PUSTAKA}

Darma, Yoce Aliah. 2013. Analisis Wacana Kritis. Bandung : Yrama Widya.

Darma, Yoce Aliah. 2014. Analisis Wacana Kritis dalam Multiperspektif. Bandung : Refika Aditama.

Fitrianingtyas, Maya; Cahyono, Bambang Eko Hari; Soleh, Dwi Rohmah. 2021. Diskriminasi dan Superioritas Perempuan dalam Naskah Drama Mega-Mega karya Arifin C.Noer. Lingua Rima: Jurnal Pendidikan Bahasa dan Sastra Indonesia. Nomor 3, Volume 10, Halaman 15-24, http://jurnal.umt.ac.id

Gaviota, Andrea. 2021. ABC Feminisme : alkar dan Riwayat Feminisme untuk Tatanan Hidup yang Adil. Yogyakarta: Bright Publisher.

Lestari, Dee. 2020. Aroma Karsa. Yogyakarta : Bentang.

Lestari, Dee, 2019. Di Balik Tirai Aroma Karsa. Yogyakarta: Bentang.

Rahayu, Sarah Syahfira; Setiadi, David; Firdaus, Asep. 2021. Eksploitasi Perempuan dalam Novel Biru Karya Fira Basuki. Lingua Rima: Jurnal Pendidikan Bahasa dan Sastra Indonesia. Nomor 3, Volume 10, Halaman 85-99, http://jurnal.umt.ac.id

Tim Penyusun. 2019. Pedoman Tesis dan Disertasi. Surakarta : Pascasarjana Kependidikan Fakultas Keguruan dan Ilmu Pendidikan Universitas Sebelas Maret.

Wardani, Septian Widya; Purnomo, Daru; Lahade, John R.. 2013. Analisis Wacana Feminisme Sara Mills Program Tupperware She Can! On Radio (Studi Kasus Pada Radio Female Semarang). Jurnal Penelitian Sosial, halaman 185-210, https://ejournal.uksw.edu 